\title{
"Ceria”
}

Jurnal Pendidikan Anak Usia Dini

ISSN 2301-9905

Volume 11, No. 2, Januari 2020

Fakultas Keguruan dan Ilmu Pendidikan- Universitas Muhammadiyah Tangerang

\section{Upaya Meningkatkan Kemampuan Logika Matematika Melaui Metode Eksperimen Pada Anak Usia 5-6 Tahun di TK Riyadhul Aulad Kecamatan Cikupa Kabupaten Tangerang}

\author{
${ }^{1}$ Sopia Apriani, ${ }^{2}$ Angger Prima Widhiasih \\ 1,2Program Studi Pendidikan Guru Pendidikan Anak Usia Dini Fakultas Keguruan \\ Dan Ilmu Pendidikan Universitas Muhammadiyah Tangerang \\ e-mail : 1sopiaapriani03@gmail.com, 2widhiasih.angger@gmail.com
}

\begin{abstract}
Abstrak
Penelitian ini dilaksanakan pada kelompok B di TK Riyadhul Aulad Kecamatan Cikupa. Kemampuan logika matematika anak masih tergolong rendah, subyek penelitian 10 anak didik terdiri laki-laki 6 dan perempuan 4 anak. Terdapat 7 anak yang masih rendah dalam kemampuan logika matematikanya, hal ini disebabkan beberapa faktor diantaranya metode pembelajaran yang monoton, kurangnya insiatif dalam menyelesaikan masalah yang ada dilingkungan, dan kurangnya minat anak dalam pembelajaran. Penelitian ini bertujuan untuk meningkatkan kemampuan logika matematika anak melalui metode eksperimen di TK Riyadhul Aulad Kecamatan Cikupa Kabupaten Tangerang. Penelitian ini menggunakan metode penelitian tindakan kelas (PTK) yang dilakukan selama 3 siklus. Hal ini terlihat dari adanya peningkatan kemampuan logika matematika anak pada pembahasan siklus 1 , siklus II dan siklus III, anak didik yang berkembang sangat baik (BSB). Berdasarkan presentase pencapaian peningkatan kemampuan logika matematika anak dari kondisi awal memperoleh persentase sebesar $45 \%$, kemudian pada siklus I adanya peningkatan yaitu mencapai 57\%, pada siklus II mengalami peningkatan kembali sebesar $74 \%$, dan pada siklus III sebesar 96\%. Sehingga presentase kenaikan dari pra siklus (kondisi awal) ke siklus I adalah sebesar $12 \%$, presentase dari silus I ke siklus II adalah sebesar $17 \%$, dan prsentase dari siklus II ke siklus III adalah sebesar 22\%. Berdasarkan hasil analisis data dan pembahasan maka dapat penulis simpulkan bahwa metode eksperimen dapat meningkatkan kemampuan logika matematika anak pada kelompok B di TK Riyadhul Aulad Kecamatan Cikupa Kabupaten Tangerang.
\end{abstract}

Kata kunci : Kemampuan Logika Matematika, Metode Eksperimen, Karakteristik Anak Usia 5-6 Tahun

\section{Pengantar}

Pendidikan anak usia dini memegang peran yang sangat penting dalam perkembangan anak karena merupakan pondasi dasar dalam menentukan perkembangan anak di kemudian hari. Masa prasekolah adalah masa yang paling tepat dalam mengembangkan 
berbagai kemampuan yang dimiliki anak, karena pada masa ini anak sangat peka menerima berbagai rangsangan dari lingkungan sekitarnya, sehingga kemampuan merupakan kekuatan yang dimiliki setiap anak untuk dapat melakukan segala aktivitas atau kegiatan. Setiap anak memiliki kemampuan yang berbeda-beda, walaupun pada hakikatnya kemampuan merupakan pembawaan manusia sejak lahir yang harus di stimulasi agar dapat terus berkembang dengan baik. Hal ini serupa dengan Munandar (1999) yang berpendapat bahwa kemampuan merupakan daya untuk melakukan suatu tindakan sebagai hasil pembawaan dan latihan (Susanto, 2011, h.97).

Menurut penelitian Howard Gardner, didalam diri setiap anak tersimpan 9 jenis kecerdasan yang siap berkembang, ia memetakan lingkup kemampuan seseorang menjadi 9 kategori, salah satunya yaitu kemampuan logika matematika. Kemampuan logika matematika ditandai dengan kemampuan berpikir secara konseptual, seperti seperti mengelola angka, berpikir logis dalam menyelesaikan masalah, dapat mengelompokkan benda sesuai dengan ukuran, bentuk, dan warna.

Berdasarkan dari pengamatan pra penelitian, tahun ajaran 2018/2019, di TK Riyadhul Aulad kelurahan Cikupa kecamatan Cikupa kabupaten Tangerang yaitu tepatnya TK B dalam proses pembelajaran yang telah dilakukan, dari 10 anak terlihat 3 anak menunjukkan kemampuan logika matematika dengan baik, sedangkan 7 anak menunjukkan kurang berkembang. Masalah yang ditemukan seperti anak belum mampu menyelesaikan maalah sederhana, mengenal prisip sebab akibat, dan mengklasifikasi benda sesuai warna dan ukuran.

Kemampuan logika matematika ditandai dengan kemampuan berpikir secara konseptual. Menurut Suyadi (2014) kemampuan logika matematika adalah kemampuan untuk menangani bilangan dan perhitungan, pola berpikir logis dan ilmiah (h.127). Dapat dilihat kemampuan ini mempunyai dua unsur, yakni matematika dan logika seperti mengelola angka, berpikir logis dalam menyelesaikan masalah, dapat mengelompokan benda sesuai dengan ukuran, bentuk, dan warna. 
Sedangkan menurut amstrong (2002) kemampuan logika matematika adalah kemampuan dalam hal angka dan logika yaitu seperti kemampuan dalam penalaran, mengurutkan, berfikir dalam pola sebab akibat, menciptakan hipotesis, mencari keteraturan konseptual atau pola numeric, dan pandangan hidupnya umumya bersifat rasional (h.3). Anak anak yang memiliki kemampuan dalam logika matematika akan sangat senang bertanya berbagai hal untuk memenuhi rasa ingin tahunya seperti ingin mengetahui sebab akibat suatu peristiwa atau gejala yang terjadi dilingkungannya, sehingga pemilihan metode pembelajaran yang tepat sangatlah berpengaruh terhadap kemampuan logika matematika anak.

Djamarah dan Zain ( 2015) berpendapat bahwa metode eksperimen (percobaan) adalah cara penyajian pembelajaran dalam melalukan suatu proses atau percobaan yang dipelajari (h.84), guru memberi kesempatan kepada anak secara perorangan atau kelompok. Sedangkan menurut Kurniasih dan Sani (2017) metode eksperimen adalah cara dimana guru dan murid bersama-sama mengerjakan sesuatu latihan atau percobaan untuk mengetahui pengaruh atau akibat dari sesuatu aksi (h.88). Pada intinya, metode eksperimen ini bertujuan untuk membuktikan kepada anak sebuah kebenaran riil dan teori-teori hukum yang berlaku, dan siswa mendapatkan jawaban langsung dari percobaan yang dilakukan.

\section{Metode}

Metode penelitian yang digunakan peneliti adalah Penelitian Tindakan Kelas (PTK), dengan subyek penelitian yaitu anak kelompok B (usia 5-6 tahun) di TK Riyadhul Aulad Kecamatan Cikupa Kabupaten Tangerang. Menurut Salahudin (2015,h. 24) penelitian tindakan kelas adalah penelitian praktis untuk memperbaiki pembelajaran didalam kelas. Penelitian ini merupakan bentuk reflektif berupa tindakan tertentu agar dapat memperbaiki praktik pembelajaran di kelas secara efektif dan efisien serta professional. Penelitian tindakan kelas merupakan jenis penelitian yang paling tepat dan strategis untuk menangani permasalahan 
dalam proses pembelajaran yang banyak dialami oleh guru. Penelitian tindakan kelas sangat bermafaat bagi guru untuk meningkatkan mutu dan hasil proses pembelajaran di kelas. Dalam Penelitian Tindakan Kelas ini tindakan yang dilakukan adalah meningkatkan kemampuan logika matematika anak usia 5-6 tahun.

Desain penelitian yang digunakan adalah model Kemmis dan Taggart, yaitu dilakukan dengan tiga siklus dan tiga tindakan atau pertemuan pada setiap siklusnya. Tahapan penelitian yang dilakukan dalam penelitian tindakan kelas ini yaitu perencanan (planning), pelaksanaa (action), pengamatan (observation), dan refleksi (reflection). Instrumen yang digunakan pada penelitian ini yaitu berupa lembar penilaian seperti lembar observasi, catatan wawancara, catatan lapangan, dan dokumentasi. Tekhnik analisa data yang digunakan adalah berupa data kuantitatif dan data kualitatif.

\section{Hasil dan Pembahasan}

Penelitian tindakan kelas di TK Riyadhul Aulad Kecamatan Cikupa Kabupaten Tangerang. Peningkatan kemampuan logika matematika anak dalam penelitian ini dilakukan dengan metode proyek dalam tiga siklus, setiap siklus terdiri dari tiga pertemuan. Kemampuan logika matematika anak dapat diukur berdasarkan tiga indikator yaitu mengenal prinsip sebab akibat, mengklasifikasi benda berdasarkan ukuran dan warna, dan menyelesaikan masalah sederhana yang ada dilingkungannya. Penerapan metode eksperimen dilakukan peneliti menggunakan eksperime yang bervariasi pada setiap siklunya. Masuk pada pembahasan siklus I yaitu tema Air, Udara, Api dengan sub tema Air dengan topik yang berbeda-beda pada setiap pertemuannya. Pada siklus I eksperimen yang dilakukan yaitu eksperimen air berwarna, adapun alat dan bahan yang digunakan dalam 
bereksperimen ini adalah air, pewarna makanan, gelas plastic dengan ukuan bebeda, spons, botol plastic, corong, dan ember.

Hasil pengamatan pada siklus I peneliti mengamati bahwa 2 orang anak mengalami peninkatan dalam kemampuan logika matematika yang daoat dilihat pada tabel hasil observasi siklus I dibawah ini :

Tabel 1.

Hasil Observasi Siklus I Kemampuan Logika Matematika

\begin{tabular}{|c|c|c|c|c|c|c|c|c|c|c|c|c|}
\hline \multirow{2}{*}{ No } & \multirow{2}{*}{$\begin{array}{l}\text { Nama } \\
\text { Anak }\end{array}$} & \multicolumn{9}{|c|}{ Indikator } & \multirow{2}{*}{$\sum$ Skor } & \multirow{2}{*}{ Presentase } \\
\hline & & \multicolumn{3}{|c|}{1} & \multicolumn{3}{|c|}{2} & \multicolumn{3}{|c|}{3} & & \\
\hline 1 & SYF & 3 & 3 & 3 & 3 & 3 & 2 & 3 & 3 & 2 & 25 & 69 \\
\hline 2 & JDN & 3 & 3 & 3 & 3 & 3 & 2 & 3 & 2 & 2 & 24 & 67 \\
\hline 3 & DKA & 2 & 2 & 2 & 2 & 2 & 1 & 2 & 2 & 2 & 17 & 47 \\
\hline 4 & DFR & 3 & 1 & 2 & 2 & 1 & 1 & 2 & 2 & 2 & 16 & 44 \\
\hline 5 & NZM & 2 & 2 & 1 & 2 & 2 & 2 & 2 & 2 & 2 & 17 & 47 \\
\hline 6 & $\mathrm{RKH}$ & 3 & 3 & 2 & 3 & 2 & 2 & 3 & 3 & 2 & 23 & 64 \\
\hline 7 & SHL & 3 & 3 & 3 & 3 & 3 & 2 & 3 & 3 & 2 & 25 & 69 \\
\hline 8 & $\mathrm{FQH}$ & 3 & 3 & 2 & 3 & 3 & 2 & 3 & 3 & 2 & 24 & 67 \\
\hline 9 & NWM & 2 & 2 & 1 & 2 & 2 & 2 & 2 & 2 & 2 & 17 & 47 \\
\hline 10 & NZC & 2 & 2 & 1 & 2 & 2 & 2 & 2 & 2 & 2 & 17 & 47 \\
\hline \multicolumn{11}{|c|}{ Jumlah } & 205 & 569 \\
\hline \multicolumn{11}{|c|}{ Rata-rata } & 20,5 & 57 \\
\hline
\end{tabular}




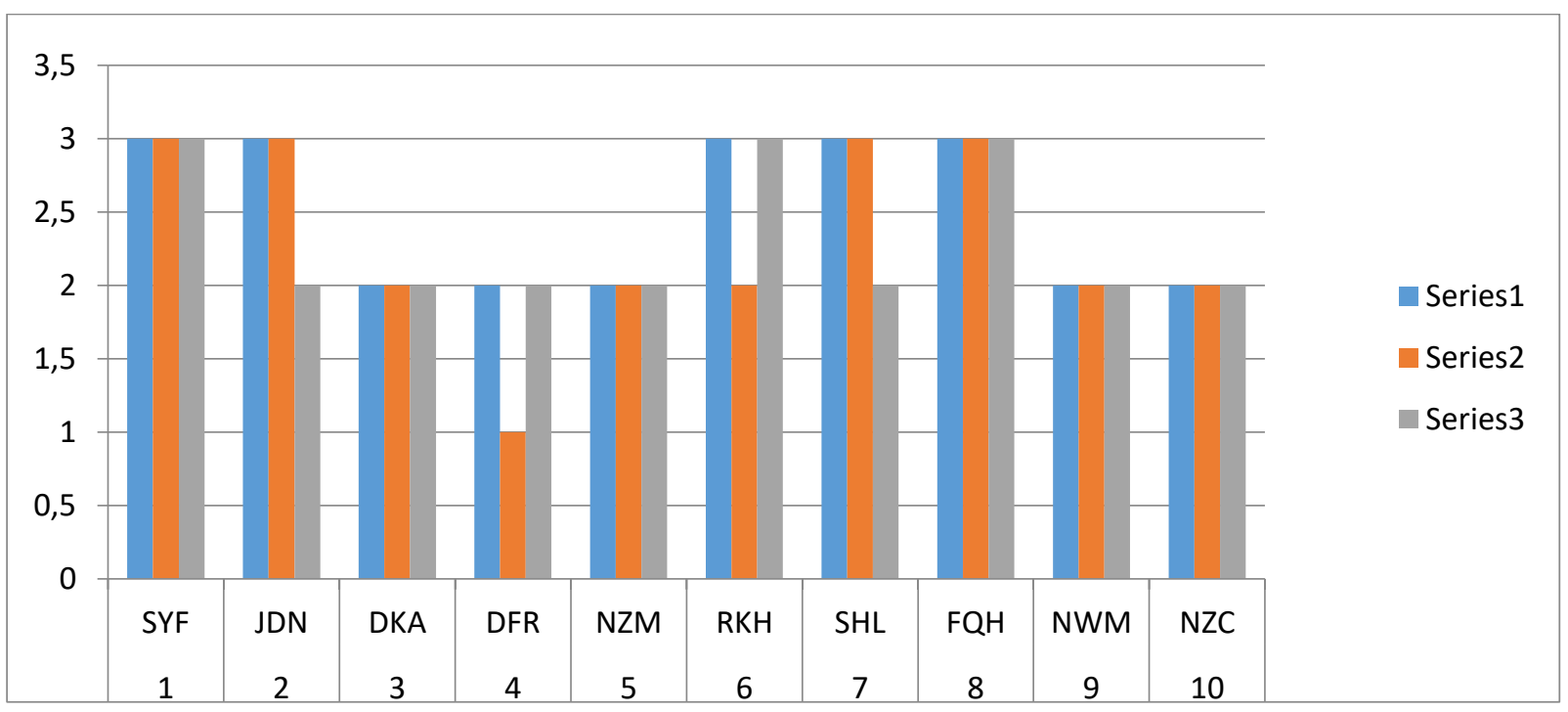

Keterangan :

1. Mengenal prinsip sebab akibat

2. Mengklasifikasi benda berdasarkan warna dan ukuran

3. Menyelesaikan masalah sederhana

Berdasarkan tabel hasil logika matematika pada siklus I ini terdapat nilai terbesar atau tertinggi dari beberapa indikator diatas yaitu pada indikator ke 1 butir pernyataan nomor 1 menyebutkan warna primer. Sedangkan berdasarkan grafik hasil kemampuan logika matematika pada siklus I dari 10 (sepuluh) anak dikelompok B hanya 5 (lima) anak berada pada indikator keberhasilan Berkembang Sesuai Haraoan (BSH), yaitu SYF, JDN, RKH SHL,FQH, dan 5 (lima) anak yaitu DKA, DFR, NZM, NWM, NZC berada pada indikator Mulai Berkembang (MB). Presentase rata-rata untuk kemampuan logika matematika pada sikls I mencapai $57 \%$ sehingga belum mencapai indikator keberhasilan dalam sebuah penelitian ini, sehingga perlu dilaksanakan siklus berikutnya yaitu siklus II. 
Tabel 2.

Hasil Observasi Siklus II Kemampuan Logika Matematika

\begin{tabular}{|c|c|c|c|c|c|c|c|c|c|c|c|c|}
\hline \multirow{2}{*}{ No } & \multirow{2}{*}{$\begin{array}{l}\text { Nama } \\
\text { Anak }\end{array}$} & \multicolumn{9}{|c|}{ Indikator } & \multirow{2}{*}{$\sum$ Skor } & \multirow{2}{*}{$\begin{array}{c}\text { Presentas } \\
\text { e }\end{array}$} \\
\hline & & \multicolumn{3}{|c|}{1} & \multicolumn{3}{|c|}{2} & \multicolumn{3}{|c|}{3} & & \\
\hline 1 & SYF & 4 & 4 & 4 & 4 & 4 & 3 & 4 & 3 & 3 & 33 & 91,7 \\
\hline 2 & JDN & 3 & 3 & 3 & 3 & 3 & 3 & 4 & 3 & 3 & 28 & 77,8 \\
\hline 3 & DKA & 3 & 2 & 2 & 3 & 2 & 2 & 3 & 3 & 3 & 23 & 61,1 \\
\hline 4 & DFR & 3 & 2 & 3 & 3 & 2 & 2 & 3 & 3 & 3 & 24 & 66,7 \\
\hline 5 & $\mathrm{NZM}$ & 3 & 2 & 2 & 3 & 2 & 2 & 3 & 2 & 2 & 21 & 58,3 \\
\hline 6 & RKH & 4 & 4 & 3 & 4 & 4 & 3 & 4 & 3 & 3 & 32 & 88,9 \\
\hline 7 & SHL & 4 & 4 & 3 & 4 & 4 & 3 & 4 & 4 & 4 & 34 & 94,4 \\
\hline 8 & $\mathrm{FQH}$ & 3 & 3 & 3 & 3 & 3 & 3 & 4 & 3 & 3 & 28 & 77,8 \\
\hline 9 & NWM & 3 & 2 & 2 & 3 & 2 & 2 & 3 & 2 & 2 & 21 & 58,3 \\
\hline 10 & NZC & 3 & 2 & 2 & 3 & 2 & 2 & 3 & 2 & 2 & 21 & 58,3 \\
\hline \multicolumn{11}{|c|}{ Jumlah } & 265 & 736 \\
\hline \multicolumn{11}{|c|}{ Rata-rata } & 26,5 & 74 \\
\hline
\end{tabular}

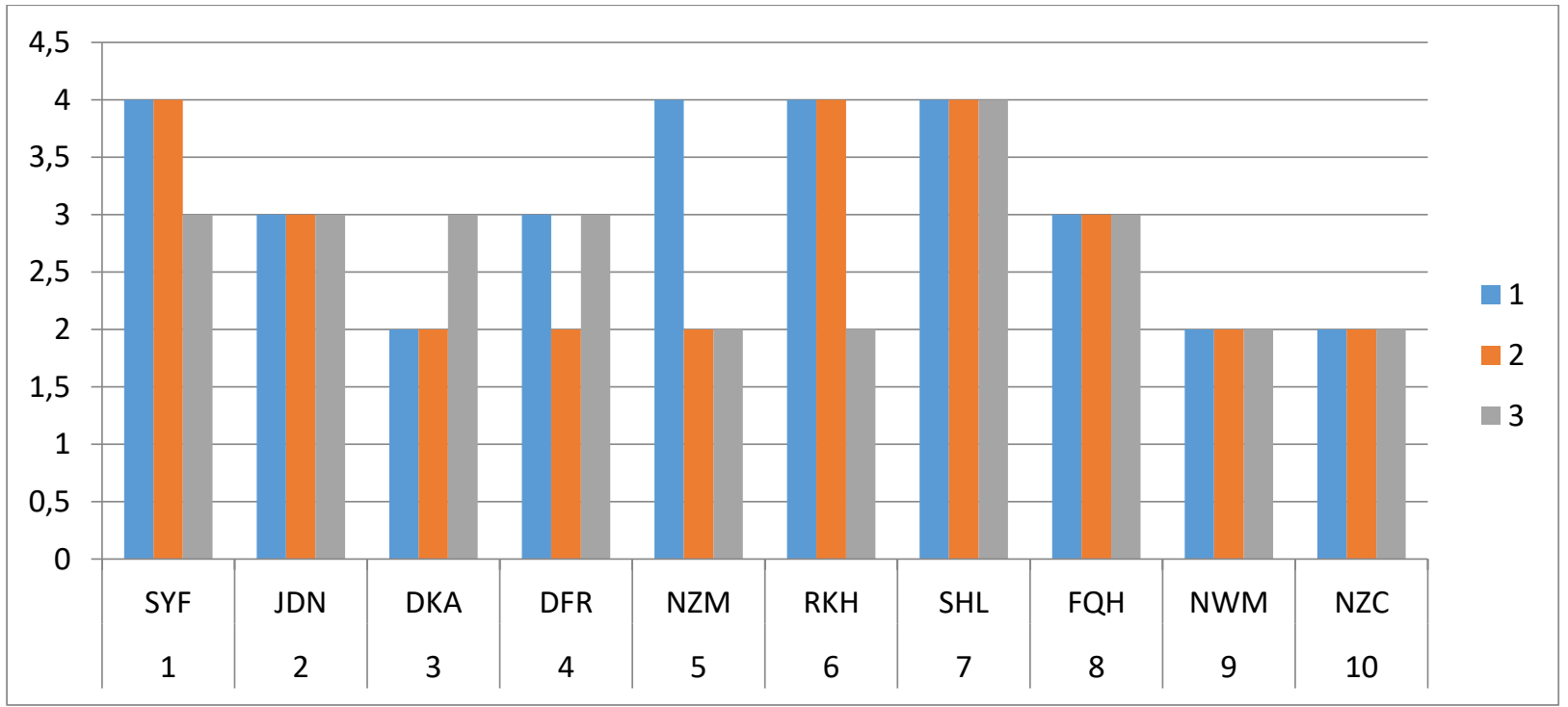

Keterangan :

1. Mengenal prinsip sebab akibat 
2. Mengklasifikasi benda berdasarkan warna dan ukuran

3. Menyelesaikan masalah sederhana

Berdasarkan tabel hasil logika matematika pada siklus I ini terdapat nilai terbesar atau tertinggi dari beberapa indikator diatas yaitu pada indikator ke 3 butir pernyataan nomor 1 menggunakan benda sesai fungsinya. Sedangkan berdasarkan grafik hasil kemampuan logika matematika pada siklus I dari 10 (sepuluh) anak dikelompok B menyatakan bahwa adanya peningkatan pada tindakan siklus II sebanyak 74\%, hal ini membuktikan bahwa dengan menggunakan metode eksperimen dalam pembelajarananak-anak mengalami peningkatan dimana 5 (lima) anak berada pada indikator keberhasilan Berkembang Sangat Baik (BSB), yaitu SYF, JDN, RKH SHL,FQH, dan 5 (lima) anak yaitu DKA, DFR, NZM, NWM, NZC berada pada indikator Berkembang Sesuai Harapan (BSH).

Kemampuan logika matematika anak dapat dilihat dari beberapa indikator yaitu mengenal prinsip sebab akibat, mengklasifikasi benda berdasarkan ukuran dan warna, dan menyelesaikan masalah sederhana yang ada dilingkungannya. Pada siklus II setelah dilakukan tindakan masih terdapat beberapa anak berada pada indikator keberhasilan Mulai Berkembang (MB) pada indikator kemampuan logika matematika tersebut, sehingga dibutuhkan penelitian pada siklus berikutnyan yaitu siklus III agar penelitian lebih relevan. 
Tabel 3.

Hasil Observasi Siklus III Kemampuan Logika Matematika

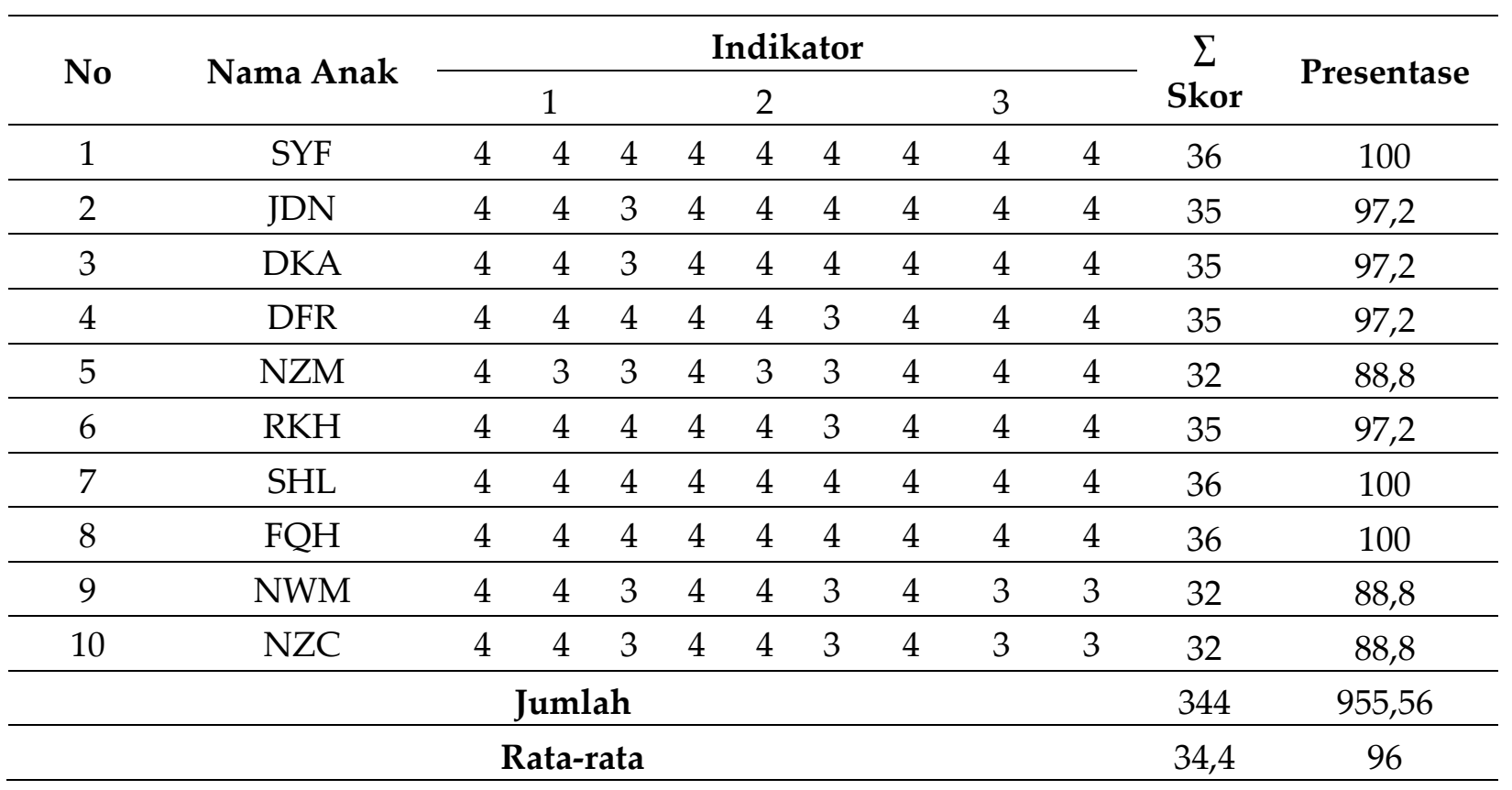

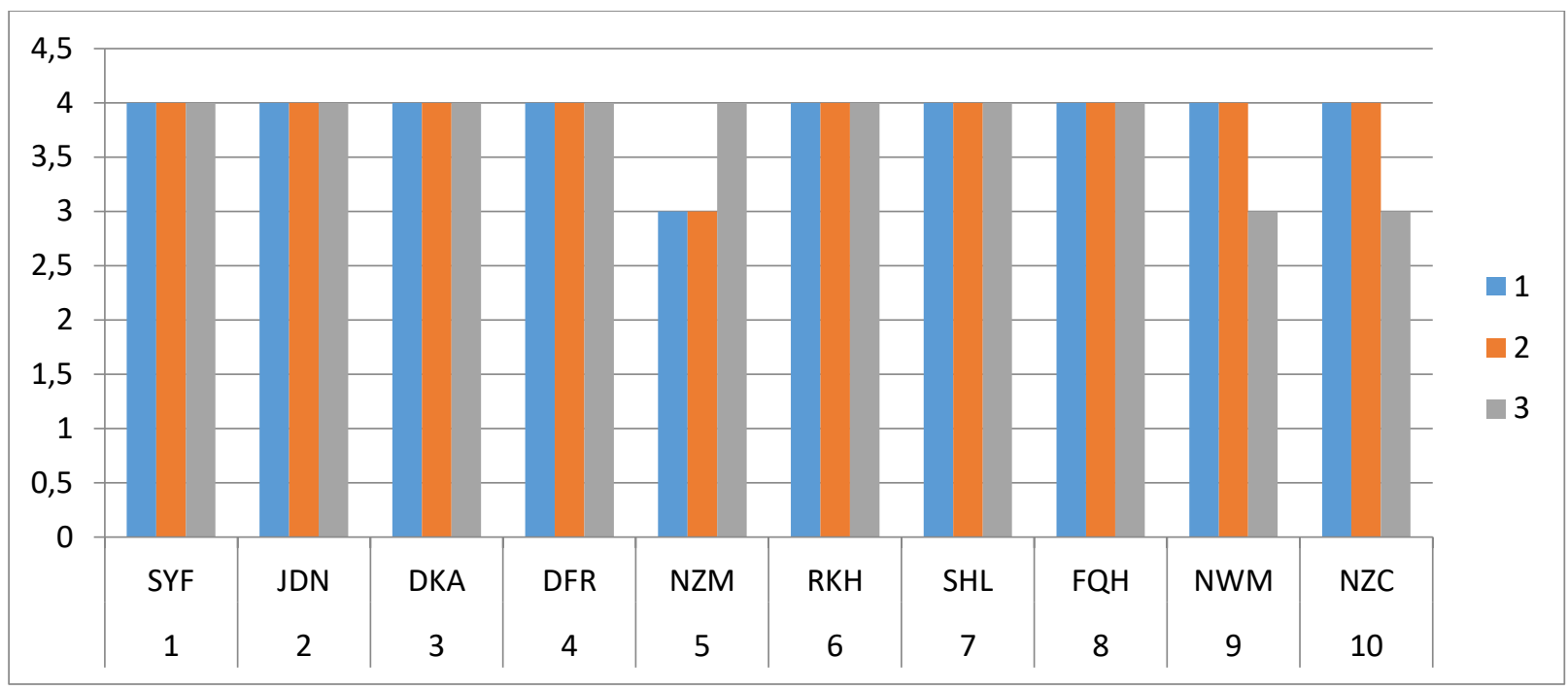

Keterangan :

1. Mengenal prinsip sebab akibat

2. Mengklasifikasi benda berdasarkan warna dan ukuran 
3. Menyelesaikan masalah sederhana

Berdasarkan tabel hasil logika matematika pada siklus I ini terdapat nilai terbesar atau tertinggi dari beberapa indikator diatas yaitu pada indikator ke 3 butir pernyataan nomor 1 menggunakan benda sesai fungsinya, pada indikator ke 1 buir pernyataan ke 1 menyebutkan warna primer, dan pada indikator ke 2 butir pernyataan ke 1 mengklasifikasi benda berdasarkan warna primer. Sedangakn berdasarkan grafik kemampuan logika matematika diatas pada siklus III seluruh anak mengalami peningkatan yang signifikan dalam hal meningkatkan kemampuan logika matematika dengan maksimal.

Berdasarkan pemaparan diatas hasil dari data kemampuan logika matematika dapat diketahui bahwa melalui metode eksperimen dapat meningkatkan kemampuan logika maematika anak. 1) Mengenal prinsip sebab akibat dengan indikator (a) anak dapat menyebutkan warna primer, (b) anak dapat menyebutkan warna sekunder, (c) anak dapat menceritakan pendapatnya, 2) Mengklasifikasikan benda berdasarkan ukuran dan warna dengan indikator, (a) anak dapat mengelompokkan benda (warna primer), (b) anak dapat mengelompokkan benda (warna sekunder), (c) anak dapat mengelompokkan benda sesuai ukuran, 3) Menyelesaikan masalah sederhana dengan indikator, (a) anak dapat menggunakan benda sesuai fungsinya dalam percobaan., (b) anak dapat mengerjakan percobaan sesuai prosedur sampai tuntas, (c) anak dapat membuktikan percobaan sampai berhasil.

Hal ini sesuai dengan penelitian yan dilakukan oleh mahasiswa Mufarizuddin (2017) dalam skripsinya yang berjudul "Peningkatan Kecerdasa Logika Matematika Anak melalui Bermain Kartu Angka Kelompok B di TK Pembina Bangkinang Kota". Kesimpulan yang diperoleh tentang meningkatkan kemampuan logika matematika anak dengan cara bermain 40 
kartu angka anak usia 5-6 tahun di TK Pembina Bangkinang Kota dikategorikan baik. Penelitian ini mempunyai tujuan yang sama yaitu untuk mengembangkan dan meningkatkan kemampuan logika matematika anak.

\section{Kesimpulan}

Berdasarkan hasil penelitian yang dilakukan berkenaan dengan upaya meningkatkan kemampuan logika matematika melalui metode eksperimen usia 5-6 tahun di Tk Riyadhul Aulad Kecamatan Cikupa Kabupaten Tangerang. Dapat di ambil kesimpulan yaitu dengan menggunakan metode eksperimen dapat meningkatkan kemampuan logika matematika di Tk Riyadhul Aulad Kecamatan Cikupa Kabupaten Tangerang, hal ini dapat dilihat pada peningkatan kemampuan logika matematika dari kondisi awal $45 \%$, pada kondisi awal ke siklus 1 meningkat sebesar $57 \%$, pada siklus 1 ke siklus II meningkat sebesar $74 \%$, dan pada siklus II ke siklus III meningkat sebesar $96 \%$. Berdasarkan kesimpulan diatas bahwa metode eksperimen dapat di terapkan oleh tenaga pendidik dalam kegiatan pembelajaran.

\section{Daftar Acuan}

Amstrong. ( 2002). Kinds Of Smart Menumukan dan Meningkatkan Kecerdasan Anda Berdasarkan Teori Multiple Intelligence. Jakarta. PT Gramedia Pustaka Utama.

Djamarah dan Zain. (2015). Strategi Belajar Mengajar. Jakarta. Rineka Cipta.

Kurniasih dan Sani. (2017). Model Pembelajaran. Jogjakarta. Kata Pena.

Mufarizuddin. 2017. Peningkatan Kecerdasan Logika Matematika Anak melalui

Bermain Kartu Angka Kelompok B di TK Pembina Bangkinang Kota. Vol.1.

Jurnal Obsesi. No.1. ISSN 2549-8959. Universitas Pahlawan Tuanku Tambusai Riau.

Susanto, Ahmad.2011. Perkembnagan Anak Usia Dini : Pengantar Dalam Berbagi Aspeknya. Jakarta:Kencana

Suyadi. (2014). Teori Pembelajaran Anak Usia Dini dalam Kajian Neurosains.

Bandung. PT Remaja Rosdakarya 